\title{
FNTA wt Allele
}

National Cancer Institute

\section{Source}

National Cancer Institute. FNTA wt Allele. NCI Thesaurus. Code C52032.

Human FNTA wild-type allele is located within 8p22-q11 and is approximately $29 \mathrm{~kb}$ in length. This allele, which encodes protein farnesyltransferase/geranylgeranyltransferase type I alpha subunit protein, is involved in the post-translational modification of certain proteins via the addition of either a farnesyl group or geranylgeranyl group. 